\title{
The impact of article processing charge waiver on conducting research in low-income countries
}

\author{
M-Nasan Abdul Baki and Mahmoud Alhaj Hussein ${ }^{*}$
}

\begin{abstract}
Health sciences research is a major tool in exchanging publications and knowledge between the various countries of the world. Researchers in developing countries barely have any financial funding from governmental or educational institutes to support their research. In low-income countries such as Syria, With less than $30 \$$ per month and almost no financial support, Syrian residency doctors are fighting to push the scientific research reality of this ongoing crisis country forward and without a doubt, APC waiver plays a crucial role in this continuing mission.
\end{abstract}

Keywords: Syria, Article processing charge, Waiver, Low-income countries, Research

Health Scientific research plays a crucial role in the never-stopping advancement of public health and clinical care. In order to achieve the maximum benefit from scientific research, the science gap between developed and developing countries should be closed. The cost of publishing research is one of the most important problems facing researchers from developing countries,especially article-processing charges (APCs) which can vary from hundreds to thousands of USD [1].

Since 2011, the ongoing crisis in Syria has had a massive effect on the lives of Syrians and made substantial damage to infrastructure, leading to a severe shortage of health facilities, a deteriorating economic situation, as well as the immigration of minds disrupting almost all aspects of life. Despite all the obstacles faced by Syrian medical researchers, there has been an increase in the amount of Syrian medical, dental, and pharmaceutical publications in the last decade [2].

To cover article-processing charges (APCs), authors tend to make use of funding that grants from governmental and educational institutes.Otherwise, researchers from Syria barely have any support and they have to conduct their research with limited funding and poor infrastructure [3]. Moreover, a salary of 73,000 Syrian pounds (SYP) per month equivalent to less than 30 USD, might be the only income for doctors throughout their residency years [4], thus it may take years to bear the costs of publishing a single scientific paper.

As a result, Syrian researchers tend to rely on the APC waivers granted by many journals to papers whose authors are based in countries classified by the World Bank as low-income economies [5].

Finally, APC waiver has a great impact on preserving the ongoing publications conducted in low-income countries such as Syria. We emphasize that the world should take real steps toward supporting authors from developing countries, which could be achieved by increasing the number of journals offering the waiver and encouraging the international and local health organizations to provide financial support. Hence, enhancing the endeavor to melt the scientific barriers between the different countries of the world. original author(s) and the source, provide a link to the Creative Commons licence, and indicate if changes were made. The images or other third party material in this article are included in the article's Creative Commons licence, unless indicated otherwise in a credit line to the material. If material is not included in the article's Creative Commons licence and your intended use is not permitted by statutory regulation or exceeds the permitted use, you will need to obtain permission directly from the copyright holder. To view a copy of this licence, visit http://creativecommons.org/licenses/by/4.0/. The Creative Commons Public Domain Dedication waiver (http://creativeco mmons.org/publicdomain/zero/1.0/) applies to the data made available in this article, unless otherwise stated in a credit line to the data. 


\section{Abbreviations}

APC: Article processing charge; USD: United States dollar.

\section{Acknowledgements}

Not applicable

\section{Authors' contributions}

All authors were a major contributor in drafting the manuscript and literature search. Both authors read and approved the final manuscript.

\section{Funding}

No funding was provided to any of the researchers for this research.

\section{Declarations}

Ethics approval and consent to participate

Not applicable.

\section{Consent for publication}

Not applicable.

\section{Availability of data and materials \\ Not applicable.}

\section{Competing interests}

The authors declare that they have no competing interests.

Received: 8 August 2021 Accepted: 8 September 2021

Published online: 15 October 2021

\section{References}

1. Ellingson MK, Shi X, Skydel JJ, Nyhan K, Lehman R, Ross JS, et al. Publishing at any cost: a cross-sectional study of the amount that medical researchers spend on open access publishing each year. BMJ Open. 2021;11:e047107.

2. Brimo Alsaman MZ, Sallah H, Badawi R, Ghawi A, Shashaa MN, Kassem LH, et al. Syrian medical, dental and pharmaceutical publication in the last decade: a bibliometric analysis. Ann West Med Surg. 2021;66:102441.

3. Alhaffar MBA, Albarshah M, Alhaffar MAA. Addressing the Problems and Challenges of Medical Research During the Syrian Crisis. 2020. https://doi. org/10.21203/rs.3.rs-31248/v1

4. Mohamad O, AlKhoury N, Abdul-Baki M-N, Alsalkini M, Shaaban R. Workplace violence toward resident doctors in public hospitals of Syria: prevalence, psychological impact, and prevention strategies: a crosssectional study. Hum Resour Health. 2021;19:8.

5. World bank country and lending groups - world bank data help desk. https://datahelpdesk.worldbank.org/knowledgebase/articles/906519. Accessed 30 Jul 2021.

\section{Publisher's Note}

Springer Nature remains neutral with regard to jurisdictional claims in published maps and institutional affiliations.
Ready to submit your research? Choose BMC and benefit from:

- fast, convenient online submission

- thorough peer review by experienced researchers in your field

- rapid publication on acceptance

- support for research data, including large and complex data types

- gold Open Access which fosters wider collaboration and increased citations

- maximum visibility for your research: over 100M website views per year

At BMC, research is always in progress.

Learn more biomedcentral.com/submissions 